\title{
The lawyer as animal in American lawyer jokes
}

\author{
Anna T. Litovkina \\ Department of Modern Philology, J. Selye University, Komárno, Slovakia \\ litovkin@terrasoft.hu
}

\begin{abstract}
In the early 1980s a new joke cycle appeared in the USA, and has continued to flourish ever since. This is the lawyer joke cycle. The greatest anger and irritation in lawyer jokes is directed at the cost of lawsuits, the high income of lawyers, as well as their greed and stinginess, ignorance and skillful manipulation, corruption and dishonesty. In American lawyer jokes there is a long tradition of comparing lawyers to different animals, generally ones which are considered dangerous, poisonous or sly - all animals which have very negative connotations. It is not surprising that, among the parallels, one can find predators of different kinds, scavengers and parasites. The animals most frequently brought up in jokes as parallels to lawyers are sharks, vultures, tigers, snakes, foxes, ticks, leeches, and rats. The goal of this study is to concentrate only on a small segment of American lawyer jokes, namely, jokes in which lawyers are compared to animals.
\end{abstract}

Keywords: lawyer, joke, American, stereotypical trait, animal.

\section{Introduction}

In the early 1980s, a new joke cycle appeared in the USA, and has continued to flourish ever since. This is the lawyer joke cycle. Lawyer jokes have been published in book form (to name just a few, see Wilde 1982; Knott 1990; Galanter 2005), and have also been displayed on various American websites. According to a 1997 Internet search by a legal journalist 3,473 sites were devoted to lawyer jokes (Yas 1997: 11), while only 17 sites displayed jokes about salesmen, 39 sites about accountant jokes, and 227 sites about doctor jokes. Theo Meder explains the sharp increase of lawyer jokes in recent years by the high legalisation of American society. He stresses: "the quantity of lawyer jokes equals the rise of the number and the social status of lawyers, the excessive wages of top-lawyers and their sky-high compensation claims" (Meder 2008: 448). According to him, this cannot be the only reason for such an expansion of lawyer jokes. "There are feelings of discontent about the impenetrable logic of justice, but above all the dominant 
'vulture culture' of suing, claiming and cashing, as exposed in the news media" (Meder 2008: 449). Christie Davies even goes further, stating:

America is government not by men but by lawyers.

Lawyers lie at the very heart of American society. American lawyers are the most American of Americans, and they represent the central American values of social mobility - as opposed to entrenched and inherited distinctions - and entail - due process and procedure as opposed to personal discretion - and, of course, the pursuit of money. The lawyers are the very essence of what it means to be an American.

(Davies 2008: 373.)

The aggressive tendency in jokes has been known of at least since the publication of Sigmund Freud's essay Jokes and Their Relation to the Unconscious in 1905 (see Freud 1960 [1905]), and has also been discussed by many humour researchers. Hostility towards law and lawyers has been a widespread phenomenon for a long time throughout the world. Grant Gilmore in The Ages of American Law stresses: "In most societies at most periods the legal profession has been heartily disliked by all non-lawyers: a recurrent dream of social reformers has been that the law should be (and can be) simplified and purified in such a way that the class of lawyers can be done away with. The dream has never withstood the cold light of waking reality" (Gilmore 1977: 1). The book entitled Devil's Advocates: The Unnatural History of Lawyers (Roth \& Roth 1989) shows the terrible scorn heaped on lawyers throughout human history, and even questions the reasons why civilisation has put up with lawyers at all. This compilation of negative anecdotes about lawyers from early times to the present includes numerous passages from the Bible, from literature, and, moreover, from the mouths of lawyers themselves. In 1911 the following humorous definition of a lawyer appeared: "LAWYER, n. One skilled in circumvention of the law" (Bierce 1911, quoted in Horrigan 2003: 64). This definition has been quoted in many legal books. The famous quotation "The first thing we do, let's kill all the lawyers" by William Shakespeare (Henry VI, Part 2, Act IV, Scene 2) has provided fruitful soil for endless transformation, as in the titles of newspaper articles about lawyers, e.g. "First Thing We Do Is Kill All the Lawyer Jokes" (Yas 1997: 11), and "Modest Alternative to Killing All Lawyers" (Miller 1991: A16). The hostile titles of some books of jokes or cartoons about lawyers also speak for themselves, e.g. Dead Lawyers and Other Pleasant Thoughts (Miller 1993), and Truly Tasteless Lawyer Jokes (Knott 1990). The perennial criticism of attorneys is illustrated as "amoral [...] guns for hire" (Horrigan 2003: 64).

At the end of the 20th century the dominant theme of American lawyer jokes was summarised as: "Lawyers are hard to understand; they charge too much; they are miserable people; they lie all the time; and they should die" (Yas 1997: 11), and that "lawyers are clever, tricky, greedy and untrustworthy" (Galanter 1998: 827). In Legal Ethics: A Comparative Study (Hazard \& Dondi 2004: 60), common complaints about lawyers from around the world were classified into five general categories:

- abuse of litigation in various ways, including using dilatory tactics and false evidence and making frivolous arguments to the courts;

- preparation of false documentation, such as false deeds, contracts, or wills;

- deceiving clients and other persons and misappropriating property;

- procrastination in dealings with clients;

- charging excessive fees. 
Why is it the lawyer, and not the representative of any other profession or occupation, who is permanently made fun of in so many American jokes? What are the dominant stereotypical traits of a lawyer? What negative features is he hated for? Does the lawyer's stereotype in American lawyer jokes contain any truth? These and many other questions could be asked in the regard to American lawyer jokes. Although it is beyond the scope of this study to discuss dominant stereotypical traits of lawyers in the American lawyer jokes displayed on various websites, I will list here just the most frequent ones (for more on the stereotypical traits of lawyers, see Galanter 1998; 2005; 2008; Davies 2008; T. Litovkina 2011a; 2011b). The greatest anger and irritation in lawyer jokes is directed at the cost of lawsuits, the high income of lawyers, and lawyers' greed and stinginess. According to the jokes, attorneys frequently bill their clients for the service they don't provide to them. While pumping more and more money out of their clients, they deliberately try to delay justice by focusing on technicalities and legal procedures. Lawyers' ignorance, skillful manipulation, corruption, and dishonesty are also common themes. Since lawyers are inveterate liars, they are not to be trusted under any circumstances. They take advantage of their own clients, and they frequently take sexual advantage of them. They are pushy, arrogant, and snobbish. They associate with the Devil. These are only the main stereotypical traits of lawyers made fun of in American lawyer jokes from the Internet. Not surprisingly, considering all these negative traits, lawyers should be exterminated (for one of the largest groups of American lawyer jokes, and also one of the themes of my other articles, see $\mathrm{T}$. Litovkina 2010b).

In American lawyer jokes there is a long tradition of comparing lawyers to different animals, generally ones which are considered dangerous, poisonous or sly - all animals which have very negative connotations. It is not surprising that, among the parallels, one can find predators of different kinds, scavengers, and parasites. The animals most frequently brought up in jokes as parallels to lawyers are sharks, vultures, tigers, snakes, foxes, ticks, leeches, and rats.

\section{The goal of the study}

The goal of this study is to concentrate only on a small segment of American lawyer jokes, namely, jokes in which lawyers are compared to animals (for a detailed discussion of this topic in Hungarian language, see T. Litovkina 2010a). All the jokes quoted and discussed in the article were found in the online references below (all of them were downloaded on 20 May 2009).

\section{Discussion: Lawyer as shark}

In America the shark image has been embraced by some lawyers as a totem, and a symbol of ferocity and power. One can even find such parallels on T-shirts, comic signs, and also in advertisements (Galanter 2002: 2229). According to Galanter, the term 'shark' with regard to 'lawyer' is not a modern invention: it was applied to lawyers before the mid-nineteenth century (Galanter 2008: 393). Not surprisingly, a lot of jokes and humorous texts displayed on different websites also embrace such parallels. Among one of them is James Fuqua's Law Jokes: Sharks and Lawyers - A Comparative Study. Let us view only the first four paragraphs of the text, which will help us to understand some features the lawyer and the emblematic predator, the shark have in common: 
"Shark" comes from the German "schurke", meaning greedy parasite. While no brave soul has gotten close enough to determine where lawyers come from, logic and common sense dictate a similar derivation.

Sharks, unlike most fish, have no bones; their skeletons are made entirely of cartilage. Lawyers, too, are spineless - as willing to argue one side of a case as the other. For the right price.

Best known as scavengers of the dead and dying, sharks have well-honed sensors with which they can track the sounds of other injured and struggling beings. They are also equipped with fine senses of smell that allow them to detect minute dilutions of blood (one part blood to one million parts water) up to one-quarter mile away. Precisely the distance a hopeful personal injury lawyer will run behind an ambulance to toss a business card.

From the moment of birth, sharks' skin is tough and rough - covered with thousands of tiny hard teeth called denticles that abrade any passerby made of softer stuff. Lawyers are also thick-skinned. Easily identified by their humorlessness and abrasive personalities, they are the bane of many social gatherings.

(Sharks and Lawyers -- A Comparative Study.)

Thus, as the text suggests, both species are parasites and scavengers of the dead and dying. Moreover, both lawyers and sharks are spineless and thick-skinned. The following joke is one of the many based on the equation of lawyers with the shark:

Q: Why won't sharks attack lawyers?

A: Professional courtesy.

(Lawyer Q and A | Funny and Jokes.)

A lawyer is depicted as a money-grabbing shark in the next text:

What happened to the banker who went to law school? Now she's a loan shark.

(Lawyers.)

In the text below, when a doctor (the profession most frequently showing up in American lawyer jokes; for more on professions and occupations in American lawyer jokes, see $\mathrm{T}$. Litovkina 2011c) gets frightened and faints after seeing a shark fin, which reminds him of a lawyer, his wife tries to calm him down by saying that it is "just a shark", also adding that he should "stop imagining that there are lawyers everywhere." Naturally, the doctor can't seriously think that there is a lawyer sticking his nose or another part of his body up out of the water! The joke's message is that, in comparison to lawyers, sharks are less harmful - there is nothing to fear when one sees them. When one sees a lawyer (or even merely thinks of seeing one!) it is entirely justified to express horror, and even to faint:

A doctor was vacationing at the seashore with his family. Suddenly, he spotted a fin sticking up in the water and fainted.

"Darling, it was just a shark," assured his wife when he came to.

"You've got to stop imagining that there are lawyers everywhere."

(Legal Fun and Market Mayhem.)

In the texts below the lawyer is compared with another predator, the vulture, a scavenger which feeds mostly on the carcasses of dead animals. Similarly to vultures which, using their acute vision and sense of smell to detect gasses produced by injured or dead animals, lawyers are 
depicted as having good noses for detecting people in need, those who are desperate. Once you are in their clutches, it is very difficult or almost impossible to extricate yourself from them:

What's the difference between a lawyer and a vulture?

The lawyer gets frequent flyer miles.

What's another difference between a lawyer and a vulture?

Removable wing tips.

What's the last difference between a lawyer and a vulture?

Vultures wait until you're dead to rip your heart out.

(Miscellaneous Lawyer Jokes.)

The main difference between the two species is that vultures don't feed on their prey when it's still alive, while lawyers attack you and "rip your heart out" (frequently grabbing your money), not waiting until your death comes.

Some other texts compare lawyers to snakes:

Q: If you drop a snake and an attorney off the Empire State Building, which one hits first? A: Who cares?

(Attorney Jokes From Snifter, Flute \& Stein - Q\&A.)

Q: Why are there so many lawyers in the U.S.?

A: Because St. Patrick chased the snakes out of Ireland.

(Lawyer Q and A | Funny and Jokes.)

Someone mistakenly left the cages open in the Reptile House at the zoo and there were snakes slithering all over the place.

Frantically, the keeper tried everything, but he couldn't get the slippery animals back into their cages. Finally, he yelled, "Quick, call a lawyer!"

"A lawyer? Why?"

"We need someone who speaks their language."

(The Best Lawyer Jokes \& Cartoons with NO annoying advertising.)

In Christianity and Judaism the serpent, which appears in the first book of the Bible (Genesis, 3:1) before Adam and Eve as an agent of the Devil and tempts them with the forbidden fruit from the Tree of Knowledge, has long been a symbol of deviousness, deception, treachery, slyness, and cunning. Lawyers in our jokes are considered to be even worse than snakes, they are more cunning and deceptive than snakes:

What's the difference between a poisonous snake and a lawyer?

... You can make a pet out of the snake.

(Bad Lawyer Jokes.)

Q: Why did God make snakes just before lawyers?

A: To practice.

(Lawyer Q and A | Funny and Jokes.)

The following text draws a parallel between the lawyer and the rattlesnake (a venomous snake, the bites of which are very often fatal) and the tiger (one of the largest predators in the world). According to the text, the lawyer is considered to be even more dangerous than the tiger or the rattlesnake, animals very few people would like to be anywhere near: 
You're trapped in a room with a tiger, a rattlesnake and a lawyer. Your gun has only two bullets. What should you do?

Shoot the lawyer. Twice.

(Miscellaneous Lawyer Jokes.)

The association of lawyers with snakes is further made in the following two jokes:

A blind rabbit and a blind snake meet each other. Neither one remembers what kind of animal they are, so they decide to feel each other.

The rabbit says, "You feel me first." The snake says okay, and he starts feeling the rabbit. He says, "Well, you have fur all over, and a little cotton tail, and two long ears, and big back feet..."

The rabbit says, "I know! I'm a rabbit! Yippee!" Then the rabbit feels the snake.

He says, "Okay, you're long and thin, and slimy all over, and there's a little forked tongue..." The snake says, "Oh no, I'm a lawyer."

(The source material is in author's possession.)

Why don't snakes bite attorneys? Professional courtesy. ${ }^{1}$

(The source material is in author's possession.)

Lawyers are sometimes also compared to the fox which, in folk perception, is an animal that has the most amazing ability to outsmart both predators and prey, as well as to be able to slip out of the most unpleasant situations (just consider the plethora of folktales with the fox as the main protagonist), an animal which possesses such qualities as cunning, cleverness, and slyness (paving the way for the comparison "sly as a fox"). Similarly to the fox, lawyers are also generally viewed as cunning, clever, and sly beings, big tricksters and liars, those who can outwit anyone with whom they are in contact. If, when compared with the fox, preference is given to the latter, and not the lawyer, it signifies quite a lot. The text below shows us that people have much more feeling for the fox than for the lawyer. Thus, when seeing a fox on the road, a driver tries to use his breaks in order to avoid hitting it. When one sees a lawyer, no such attempt is made to save him:

Q: How can you tell the difference between a lawyer lying dead in the road and a fox?

A: With the fox, you usually see skid marks. ${ }^{2}$

(The source material is in author's possession.)

When compared to a skunk, an animal known for its ability to excrete a strong, foulsmelling odor, again, in all the jokes the preference is to the skunk, and not to the lawyer:

Q: What is the difference between a dead lawyer and a squished skunk in the road? A: The vultures will eat the skunk.

(The source material is in author's possession.)

Q: What is the difference between a lawyer and a skunk?

A: Nobody wants to hit a skunk.

(The source material is in author's possession.) 
Many texts compare attorneys in law with various blood-feeding beings:

Q: Why is going to a meeting of the Bar Association like going into a bait shop?

A: Because of the abundance of suckers, leeches, maggots, and nightcrawlers.

(Lawyer Q and A | Funny and Jokes.)

Stanley Livingston, in deepest Africa, finds a cannibal restaurant. The specialty of the day is brains fried doctor brains for twenty bucks, sautéed architect brains for twenty-five bucks, and roasted attorney brains for two hundred bucks. Livingston, perplexed, asks the waiter why the attorney brains are so costly. The waiter snorts, "Do you know what a job it is to clean those suckers?"

(The source material is in author's possession.)

Some other texts bring up parallels with the tick, a parasite which lives on blood, which is also a vector of a number of diseases, including Lyme disease, or tick-borne meningoencephalitis:

Q: What's the difference between a tick and a lawyer?

A: The tick drops off after you're dead.

(Lawsongs, Inc. - Lawyer Jokes.)

The association of the lawyer with the leech, a type of annelid, some of which feed on blood, and which have been used for clinical bloodletting for thousands of years, is made in the following jokes:

Q: What's the difference between a lawyer and a leech?

A: When you die, a leech will stop sucking your blood and drop off.

(The Best Lawyer Jokes \& Cartoons with NO annoying advertising.)

Q: How do you know when your divorce is getting ugly?

A: When your lawyer doesn't seem like a bloodsucking leech anymore.

(The source material is in author's possession.)

Several texts have been aimed at comparing lawyers to another blood-feeding creature (although not an animal) - the vampire - a mythological or folkloric being generally identified as feeding on human blood:

Q: What's the difference between a lawyer and a vampire?

A: A vampire only sucks blood at night.

(Lawsongs, Inc. - Lawyer Jokes.)

It is vampires that learn from lawyers how to suck blood, and not vice versa:

Q: Where do vampires learn to suck blood?

A: Law school.

(Lawyers.)

Naturally "sucking blood" in American lawyer jokes is a metaphor for lawyers sucking their clients' energy and spirit, as well as pumping them of their money. Indeed, lawyers are very frequently called "money grabbers". As we can see from the texts above, there is a tremendous difference between lawyers and other bloodsuckers: while vampires suck your blood only at 
night, and they and leeches and ticks do it while you are alive, lawyers suck your blood all the time, regardless of the time of day and regardless of whether you are alive or dead.

Another animal which is quite often brought up in lawyer jokes is the rat, an animal frequently used nowadays for medical experiments. Rats are seen as vicious, unclean, parasitic animals, being blamed for spreading disease (for example, pestilence - the 14th-century plague called the Black Death). Rats are also associated with aggression, war, and death. As we learn from the joke ${ }^{3}$ below, like rats, lawyers are considered as deserving eradication:

The National Institute of Health has announced that it will no longer be using rats for medical experiments. In their place, they will use lawyers. They have given three reasons for this decision:

There are now more lawyers than there are rats.

The medical researchers don't become as emotionally attached to the lawyers as they did to the rats.

No matter how hard you try, there are some things that rats won't do.

(Jokes About Lawyers.)

The fact that clear preference in deciding which (lawyers or rats) should be used for medical experiments (that is, be expended) is given to lawyers indicates that, similarly to rats, lawyers are just pests which American society should remove. The three reasons ${ }^{4}$ for such preferences are quite forthright, and don't need to be further explained. The joke is also a clear manifestation of the retaliation of doctors (as well as scientists, and laboratory workers involved in medical experiments). One of the reasons for such revenge might be the fact that doctors are nowadays being permanently sued in American society by attorneys.

When the man in the joke below realizes that the brass rat he has just bought in an antique store attracts, like a magnet, an army of live rats, he goes back to the store in order to get a brass lawyer. Thus, his hope is that an army of lawyers will start following the brass lawyer and if he throws it into the river he might be able to destroy thousands of them:

A man came across a striking brass rat in an antique store and decided it would look great on his desk. He paid $\$ 100$ for it but was surprised when the proprietor insisted it was non-returnable. He said, "It's been returned twice already, and I don't want to see it again."

Leaving the store, the man saw a couple of rats scurrying around the corner; several more were near his car. As he drove, rats appeared from the gutters and side streets until he was nearly overwhelmed. In panic, he threw the brass rat over a bridge railing into a river, and witnessed the army of live rats follow it into the depths.

The man hurried back to the store, but the owner cut him short, saying, "Look, I told you there would be no returns." The man quickly replied, "Oh no, that's fine. I was just wondering if you had a brass lawyer."

(The source material is in author's possession.)

The joke above reminds us of a historic story about rats and their catching, The Pied Piper of Hamelin, which has appeared many times in popular culture, having inspired the realms of literature, film, theatre, etc. According to the legend, at the end of 13th century while the German town of Hamelin was suffering from a rat infestation, a rat-catcher promised a solution for the problem, and playing a magical pipe, he managed to lead rats away from the town, into a river nearby, in which they were drowned. Despite his success and the town's promise, the rat-catcher was refused his payment. The piper, seeking proper revenge, decided to play his magic pipe again. His goal that time was to abduct the town's children. The children of Hamelin were lured 
into a cave and never seen again (according to some versions two were left behind, see also Mieder 2007).

There are, in addition, jokes in which lawyers are associated with some other animals (bulldog, pit bull terrier, porcupine, donkey, and pig), for example:

Q: How do you tell the difference between a lawyer and a bulldog?

A: The bulldog generally has enough sense to know when to let go.

(The source material is in author's possession.)

Q: What's the difference between an attorney and a pit bull?

A: Jewelry.

(The source material is in author's possession.)

Q: What's the difference between a porcupine and a Mercedes Benz full of lawyers? A: The porcupine has pricks on the outside.

(Lawyer Q and A | Funny and Jokes.)

A lawyer was on vacation in a small farming town. While walking through the streets on a quiet Sunday morning, he came upon a large crowd gathered by the side of the road. Going by instinct, the lawyer figured that there was some sort of auto collision. He was eager to get to the injured parties but couldn't get near the car. Being a clever sort, he started shouting loudly, "Let me through! Let me through! I am the son of the victim."

The crowd made way for him. Lying in front of the car was a donkey.

(The Best Lawyer Jokes \& Cartoons with NO annoying advertising.)

What is the difference between pigs and lawyers?

You can learn to respect a pig.

(The source material is in author's possession.)

\section{Conclusion}

As we have seen, American lawyer jokes frequently draw parallels between lawyers and animals. Lawyers are generally compared to animals which are the epitomes of predatory types, or scavengers (sharks, vultures, and tigers), symbols of slyness, deception and cunning (snakes and foxes), or parasites (ticks) which, in folk interpretation, have negative, dirty, or dangerous connotations (pit bulls and pigs). In the jokes, similarly to animals sucking people's blood (leeches and ticks), lawyers pump their clients of their money. The jokes even parallel the lawyer with the rat, a vicious, dirty animal, associated in people's minds with aggression, war, and death. Similarly to the rat, a vicious, unclean, and parasitic animal, spreading disease, and associated in people's minds with aggression, war, and death, a pest which has to be exterminated, the jokes suggest that lawyers should also be removed from society.

\section{Notes}

${ }^{1}$ This joke is a variant of the joke quoted earlier about a shark.

${ }^{2}$ This joke can be found as many variants on different websites. Thus, instead of the fox, there might be some other animals, e.g. a dog or a snake (the animal discussed earlier), and, 
similarly to the joke about the fox, in the following joke no attempt to slow down is made when the driver sees a lawyer on the road:

Q: What's the difference between a lawyer and a snake run down on the highway?

A: Skid marks in front of the snake.

${ }^{3}$ One can find dozens of variants of this on different websites.

(Bad Lawyer Jokes.)

${ }^{4}$ Some websites give even more reasons for such preferences.

\section{Primary sources}

Attorney Jokes From Snifter, Flute \& Stein - Q\&A. Available online: http://www.9timezones.com/ia/lawques.htm [Accessed 23 November 2015].

Bad Lawyer Jokes. Available online: http://www.extremelysmart.com/humor/lawyerjokes.php [Accessed 23 November 2015].

Jokes About Lawyers. Available online: http://www.terry.co.uk/jokes01.html_[Accessed 23 November 2015].

Lawyer Q and A | Funny and Jokes. Available online: http://www.funnyandjokes.com/lawyer-qand-a.html [Accessed 23 November 2015].

Lawyers. Available online: http://www.kaila.pl/humor/lawyers.htm [Accessed 23 November 2015].

Lawsongs, Inc. - Lawyer Jokes. Available online: http://www.lawsongs.com/lawyer_jokes.html [Accessed 23 November 2015].

Legal Fun and Market Mayhem. Available online: http://www.resourcesforattorneys.com/lawyerjokes.html [Accessed 23 November 2015].

Miscellaneous Lawyer Jokes. Available online: http://wilk4.com/humor/humorm353_lawyers.htm [Accessed 23 November 2015].

Sharks and Lawyers - A Comparative Study. Available online: http://www.jamesfuqua.com/lawyers/jokes/sharks.shtml [Accessed 23 November 2015].

The Best Lawyer Jokes \& Cartoons with NO annoying advertising. Available online: http://www.swapmeetdave.com/Humor/Lawyer.htm [Accessed 23 November 2015].

\section{References}

Bierce, A. (1911). The Devil's Dictionary. Available online: http://www.dict.org/bin/Dict [Accessed 5 May 2010].

Davies, Ch. (2008). 'American jokes about lawyers'. HUMOR: International Journal of Humor Research 21 (4), pp. 369-386.

Freud, S. (1960 [1905]). Jokes and Their Relation to the Unconscious. Translated and edited by James Strachey. New York: W. W. Norton \& Company, Inc.

Galanter, M. (1998). 'The faces of mistrust: the images of lawyers in public opinion, jokes and political discourse'. University of Cincinnati Law Review 66 (3), pp. 805-845.

Galanter, M. (2002). 'Changing legal consciousness in America in the view from the joke corpus'. Cardozo Law Review 23 (6), pp. 2223-2240.

Galanter, M. (2005). Lowering the Bar: Lawyer Jokes and Legal Culture. Madison: University of Wisconsin Press. 
Galanter, M. (2008). 'The great American lawyer joke explosion'. HUMOR: International Journal of Humor Research 21 (4), pp. 387-413.

Gilmore, G. (1977). The Ages of American Law. New Haven: Yale University Press.

Hazard, Jr., G. C. \& Dondi, A. (2004). Legal Ethics: A Comparative Study. Stanford University Press.

Horrigan, B. (2003). Adventures in Law and Justice: Exploring Big Legal Questions in Everyday Life. Sydney: University of New South Wales Press.

Knott, B. (1990). Truly Tasteless Lawyer Jokes. New York: St. Martin's Paperbacks.

T. Litovkina, A. (2009). 'Law is hell: Death and the afterlife in American lawyer jokes'. Acta Juridica Hungarica 50 (3), pp. 311-328.

T. Litovkina, A. (2010a). Az ügyvédek mint állatfaj - amerikai ügyvédviccek elemzése, in T. Litovkina, A., Barta, P. \& Hidasi, J. (eds.), A humor dimenziói. Budapest: Tinta Könyvkiadó - BGF, pp. 191-200.

T. Litovkina, A. (2010b). Az ügyvédekkel történő leszámolás különböző módjai az amerikai ügyvédviccekben, in Gecső, T. \& Sárdi, Cs. (eds.), Új módszerek az alkalmazott nyelvészeti kutatásban. Székesfehérvár: KJF \& Budapest: Tinta Könyvkiadó, pp. 191-197.

T. Litovkina, A. (2011a). 'Greed, lies and negotiable justice: Stereotyped lawyers in American lawyer jokes'. Acta Ethnographica Hungarica 56 (1), pp. 227-248.

T. Litovkina, A. (2011b). 'Where there's a will there's a lawyer's bill': Lawyers in AngloAmerican anti-proverbs'. Acta Juridica Hungarica 52 (1), pp. 82-96.

T. Litovkina, A. (2011c). "Advice is cheap... except when you consult a doctor or lawyer or tax accountant": Lawyers, doctors and representatives of other professions in American lawyer jokes.' Available online: $\quad$ http://www.comunesanzenodimontagna.it/wpcontent/uploads/2012/01/4_1.pdf [Accessed 14 November 2013].

Meder, Th. (2008). 'Tales of tricks and greed and big surprises: Laymen's views of the Law in Dutch oral narrative'. HUMOR: International Journal of Humor Research 21 (4), pp. 435454.

Mieder, W. (2007). The Pied Piper: A Handbook. Westport, Conn: Greenwood Press.

Miller, D. W. (1993). Dead Lawyers and Other Pleasant Thoughts. New York: Random House.

Miller, R. R. (1991). 'A modest alternative to killing all lawyers." Wall Street Journal, 28 October, p. A16, Col. 3.

Roth, A. \& Roth, J. (1989). Devil's Advocates: The Unnatural History of Lawyers. Berkeley: Nolo Press.

Wilde, L. (1982). The Official Lawyers' Joke Book. New York: Bantam.

Yas, D. L. (1997). 'First thing we do is kill all the lawyer jokes'. Massachusetts Lawyers Weekly, 20 October, p. 11. 